IRA-International Journal of Management \& Social Sciences

ISSN 2455-2267; Vol.06, Issue 03 (2017)

Pg. no. 419-428

Institute of Research Advances

https://research-advances.org/index.php/RAJMSS

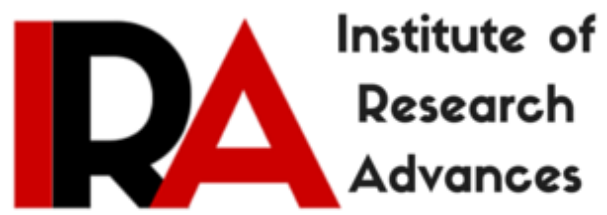

\title{
Motivation, Competence and Organizational Commitment's Effect on Lecturers' Job Satisfaction and Lecturers Performance
}

\author{
Arminas Hairuddin $^{1}$, Mursalim Umar Gani ${ }^{2}$, Bahar Sinring ${ }^{3}$, Zaenal Arifin ${ }^{4}$ \\ ${ }^{1}$ Doctoral Student in Faculty of Economics, Muslim University of Indonesia, Indonesia. \\ ${ }^{2,3,4}$ Faculty of Economics, Muslim University of Indonesia, Indonesia .
}

Type of Review: Peer Reviewed.

DOI: http://dx.doi.org/10.21013/jmss.v6.n3.p8

\section{How to cite this paper:}

Hairuddin, A., Gani, M., Sinring, B., \& Arifin, Z. (2017). Motivation, Competence and Organizational Commitment's Effect on Lecturers' Job Satisfaction and Lecturers Performance. IRA-International Journal of Management \& Social Sciences (ISSN 2455-2267), 6(3), 419-428. doi:http://dx.doi.org/10.21013/jmss.v6.n3.p8

(C) Institute of Research Advances

\section{(c) EY-NC}

This work is licensed under a Creative Commons Attribution-Non Commercial 4.0 International License subject to proper citation to the publication source of the work.

Disclaimer: The scholarly papers as reviewed and published by the Institute of Research Advances (IRA) are the views and opinions of their respective authors and are not the views or opinions of the IRA. The IRA disclaims of any harm or loss caused due to the published content to any party. 


\begin{abstract}
Purpose of this study was to analyze the influence of motivation, competence and organizational commitment to job satisfaction lecturers, to analyze the influence motivation, competence and commitment of the organization to the performance of lecturers, to analyze the effects of job satisfaction on the performance of lecturers, and to analyze the influence of motivation, competence and organizational commitment indirectly through job satisfaction on the performance of lecturers. The study population is of 409 lecturers. Determination of the sample using the formula Slovin obtained as many as 202 respondents from the correspondence through the intranet Ministry of Industry of the Republic of Indonesia. Data from the questionnaires were analyzed with structural equation modeling the help of using AMOS (Analysis of Moment Structures) Version 18. The results showed that work motivation has a positive and significant effect on lecturers' job satisfaction and lecturers' performance. Competence has a positive and insignificant effect on lecturers' job satisfaction, but significant on lecturers performance. Organizational commitment has a positive and significant effect on lecturers' job satisfaction and lecturers' performance. Lecturers' job satisfaction has a positive and significant effect on lecturers' performance. The Effect of Lecturers' job satisfaction proved to be significant in explaining the effect of work motivation, competence and organizational commitment on lecturers' performance.
\end{abstract}

Keywords: Motivation, competence, organizational commitment, satisfaction and performance

\title{
Introduction
}

The development of industry that continues to advance in line with the demands of globalization requires the realization of the industrial world is competitive and capable of winning the competition. On the basis of this being the instruction of the Ministry of Industry of the Republic of Indonesia to socialize at various educational institutions to increase output in the industry meet the challenges of the world today. It has become very important to be pursued and anticipated so as not to cause the gap between the demands of industry with the share of industry players. Included in this case is to meet global competition such as the free trade era in taking part in the Asian Economic Community (AEC) and the activities of the economy and national industry.

Upon consideration of this, the Ministry of Industry of the Republic of Indonesia is trying to improve and make changes oriented competitive advantage as well as the creation of human resources that are reliable and professional in the field of industry. In connection with this, the Ministry of Industry seeks to improve strength in the field of education related to industry as it exists in the scope of Polytechnic education unit. The success of education many determine the direction of progress and development of the industrial world in Indonesia, because it is important to see the achievement of faculty performance in the scope of the Ministry of Industry is conducting education and teaching, research, community service activities and other supporting activities in a variety of technology development.

Understanding the world of education in the scope of the Ministry of Industry of the Republic of Indonesia, which number as many as eight (8) units of polytechnic education, namely; (1) Polytechnic Chemical Technology Industry (PTKI) Medan; (2) The College of Textile Technology (STTT) Bandung; (3) Academy of Industrial Technology (ATI) Padang; (4) Academy of Industrial Technology (ATI) Makassar; (5) Chemical Analysis Academy (AKA) Bogor; (6) the Academy of Leather Technology (ATK) Yogyakarta; (7) Corporate Leadership Academy (APP) Jakarta; and (8) School of Industrial Management (STMI) Jakarta. The eighth polytechnic is expected to respond to the challenges and the development of the industrial world.

Understanding the importance of development and progress of the industry to see the reality of this 
polytechnic eighth, based on the results of preliminary observations researchers found no empirical gaps that need to be observed further, especially with regard to the performance of polytechnic lecturers. The interesting phenomenon to be observed by the fact that it was found that in the performance of lecturers in the last five years, there is a tendency to decline. The cause of this decline due to the polytechnic lecturers not optimal in developing teaching materials in the fields of education, lack of conducting research, service to the community which is less actualized and other supporting activities relating to the Tri Dharma College. This adversely affects the performance of lecturers. Based on data from the Ministry of Industry of the Republic of Indonesia, indicated the percentage of performance data Polytechnic lecturers in the last five years as a result of performance evaluation of lecturers.

Table 1 Data Percentage of Performance Lecturer Polytechnic in the Environment Ministry of Industry of the Republic of Indonesia

\begin{tabular}{|c|c|c|c|c|c|c|}
\hline \multirow[b]{2}{*}{ Year\% } & \multicolumn{4}{|c|}{ Lecturer Performance (\%) } & \multirow{2}{*}{$\begin{array}{c}\text { Total } \\
\text { Performance } \\
(\%)\end{array}$} & \multirow{2}{*}{$\begin{array}{c}\text { Expected } \\
\text { Performance } \\
(\%)\end{array}$} \\
\hline & Education & Research & $\begin{array}{c}\text { Community } \\
\text { Service }\end{array}$ & $\begin{array}{c}\text { Support } \\
\text { Activities }\end{array}$ & & \\
\hline 2012 & 44.4 & 40.6 & 7.8 & 7.2 & 100.0 & $>95$ \\
\hline 2013 & 43.5 & 42.5 & 7.5 & 6.5 & 100.0 & $>95$ \\
\hline 2014 & 43.4 & 36.7 & 7.4 & 6.0 & 93.5 & $>95$ \\
\hline 2015 & 43.7 & 38.4 & 6.8 & 5.8 & 94.7 & $>95$ \\
\hline 2016 & 43.5 & 37.2 & 6.5 & 5.6 & 92.8 & $>95$ \\
\hline Rata2 & 43.7 & 39.1 & 7.2 & 6.2 & 96.2 & \\
\hline
\end{tabular}

Source: Ministry of Industry - Republic of Indonesia (2017).

According the table 1 shows that the performance of lecturers under the auspices of the Ministry of Industry of the Republic of Indonesia in particular, seen from the weight of faculty performance ratings in the last five years has decreased from $100 \%$ to $92.8 \%$, where in the last three years did not achieve the expected performance. More details can be elaborated faculty performance based aspects of education and teaching the average achieved in the five years that is equal to $43.7 \%$, which means the burden of teaching unmet of lecturers to take courses at nine credit semester system, in the field of research percentage only reaching an average of $39.1 \%$ led the research activity of faculty is not optimal to always propose a research proposal to be published, both for individual research, applied research or research grants for public research.

Aspects of community service is visible only reached an average of $7.2 \%$, which means the actualization of community service carried out by the lecturers have not been optimized in accordance with the demands of service to the community, especially with regard to lectures and practical work profession industry sector. Aspects of supporting Tridharma achieved average new 6.2\% indicating that they need to be given opportunities to every faculty to engage in various activities of regional and international forums as support activities.

The cause of faculty performance is declining due to several factors, such as motivation, competence, organizational commitment and job satisfaction in accordance dynamics faced. The following facts phenomenon that occurred in 2012 there was a trend of lecturers in teaching less motivated because of non-fulfillment of motivation to excel. In 2013 to 2014 indicate a lack of opportunities for lecturers to improve their competence in a professional manner in accordance with the development of the courses carried. In 2015 the cause of faculty performance drops due to the lack of commitment to advance the organization held a teaching organization. And in 2016 seen many professors are not satisfied with the work of the lecture is achieved. This is why every year the performance of lecturers has decreased.

Visible are many professors who have not yet developed its performance in the field of education and 
teaching, especially in various activities both academic lectures, scientific lectures and scientific meetings. Lecturers are still many who do not involve themselves in the field of research, especially related to the field of industrial research, competition research collectively and numerous scientific research papers / journal industry. There are still many lecturers who have not been doing community service, especially with regard to college activities and professional field work for the industrial sector, including in the field of support activities such as participating in various regional and international forums.

This is the consideration to see where the performance of lecturers in various dimensions prospective happened, so research is motivated from a phenomenon found in the education unit polytechnic lecturer Scope of the Ministry of Industry of the Republic of Indonesia. Supposedly every lecturer should play an important role in improving its performance in accordance with their contribution to Tridharma carried. Faculty performance assessed on the amount of the contribution of lecturers in conducting activities in the field of education and teaching, research, community service and support activities.

The decline in unit polytechnic faculty performance in the scope of the Ministry of Industry has always affected by job dissatisfaction lecturers in developing the Three Pillars of Tertiary Education. The phenomenon of job satisfaction lecturers low, reflected in the low responsibility for running professional duty well, innovation lecturers low in the advancement of teaching, lack of achievement in the lectures, the recognition of low credibility in the lecture and the lack of attention on the work itself as a profession be engaged with a vengeance. Low job satisfaction lecturers need to be repaired and upgraded in satisfaction inflate responsible, to realize development lecture, realize achievement, gain recognition and credibility of the institution where the teaching profession enjoys the work of lecturers. Job satisfaction lecturer is expected to improve its performance, although in reality there are many professors who have not been able to show a good performance in accordance Tridharma carried because of the motivation, competence and commitment of lecturers still low. These three variables are directly and indirectly affect job satisfaction and performance of lecturers.

The work low ethic lecturer influence on job satisfaction and performance in developing the profession, especially with regard to achievement motivation. The phenomenon is found among some faculty visible in the process of teaching often show low motivation to teach. Indeed, motivation is an urge from within or from outside a person to excel, but they are not. Reality on the faculty of self-actualization seen in conducting teaching activities lackluster, like a lazy teaching, doing research, not fostering community service and participate in various activities to support Three Pillars of Tertiary Education services. Motivation lecturer low because not able to show achievements that can be recognized to deserve the award, motivational lecturer is also low due to among the lecturers rarely socialize, making it difficult to cooperate and communicate effectively in negotiating the development of teaching materials that affect job satisfaction and performance of lecturers.

Furthermore, another reality faced by lecturers who work on education unit Polytechnic which influence the competence of lecturers are still low, both directly and indirectly to the satisfaction and the performance of lecturers. Competence in essence is the ability of a person in accordance with the profession carried on in managing the potential to achieve job satisfaction and improve its performance. Talking about the competence of lecturers always consider aspects of Pedagogy on faculty insight, professional ability in teaching, personal skills and social skills in carrying out its activities as a lecturer, in which lecturers are required to have the competence to fulfill the work satisfaction and improve its performance. But the reality looks still exist between the education unit polytechnic lecturers who have the competence has not been optimal effect on the low level of job satisfaction so that the level of faculty performance becomes low.

Including the need to be observed is related to the commitment of lecturers with the organization in order 
to teach, among the lecturers there that show commitment to work remains low in improving satisfaction and performance. There are several lecturers level of commitment organizational lower in performing their duties and functions in accordance with the Three Pillars of Tertiary Education, in particular to promote the organization (affective commitment), carry out all the rules of the organization (normative commitment), committed to realizing organizational achievement (continuance commitment) and committed to realize the achievement of organizational goals (prospective commitment) that led to the achievement of the work of an effect on job satisfaction and performance lecturers. Evidence that organizational commitment owned lecturers still low seen from the lack of initiative advancing the institution where professors work, does not comply with work rules that have been set, low effort to develop the work presented and no ability to maintain the results achieved. Low organizational commitment lead to job satisfaction and high performance of lecturers.

\section{Literature Review and Hypothesis testing}

There are five variables were observed consisting of three exogenous variables and two endogenous variables. An exogenous variable in this study consists of motivation, competence and commitment to the organization. While the endogenous variable in the form of a variable between job satisfaction and that is the dependent variable is the performance.

\section{Work Motivation}

McClelland's Human Motivation Theory on the need for achievement explained that people will be motivated because of the need of success (Seed for achievement/n-Ach), need for affiliation (need for affiliation/n-Aff) and power needs (need for power/n-Pow) (Rival, 2008:211). Achievement motivation is needed by every faculty to improve customer satisfaction and performance. In the actualization third requirement is embodied in the form of motivation actualization of work (self-actualization), awards (self esteem), cooperation, communication and compensation, which is very encouraging, encourage and become a motive for lecturers to perform the activity teaching in lectures to achieve job satisfaction and improve the performance of lecturers.

Understanding the motivation of this achievement, supported by several previous investigators, that influence work motivation negative and significant impact on job satisfaction (Nabizadeh, 2012), a different result explains that motivation has positive and insignificant effect on lecturers performance (Sosiawan, 2013), motivation positive and significant effect on performance (Andi Harmoko, 2014), work motivation has a positive and significant effect on job satisfaction and performance (Wilson, 2013).

$\mathrm{H}_{1} \quad$ Work motivation has a positive and significant effect on lecturers' job satisfaction

$\mathrm{H}_{2} \quad$ Work motivation has a positive and significant effect on lecturers performance

\section{Competence}

Application of the theory of competency assessment, including explaining that professionalism is a competency assessment. Someone visits of professionalism in this case the ability of knowledge pedagogy, professional skills, personality traits and social interaction as competence. This was taken into consideration in assessing the competency of a lecturer in achieving satisfaction and performance (Warritten, 2007:51).

Observing the importance of the assessment of their competence lecturers, some previous studies provide evidence inconsistent, that competence positive and significant impact on satisfaction and performance (Sosiawan, 2013), competency positive effect and no significant effect on job satisfaction, but positive and significant effect on performance ( Hunt Michael, 2011), the competence of positive and significant impact on job satisfaction and performance (Jack Harmston, 2008), the competence of a significant 
negative effect on job satisfaction (Wilson, 2013), the competence of a significant negative effect on satisfaction and performance (Harprianti 2010 ; George Michael, 2011).

$\mathrm{H}_{3} \quad$ Competence has a positive and significant effect on lecturers' job satisfaction

$\mathrm{H}_{4} \quad$ Competence has a positive and significant effect on lecturers performance

\section{Organizational Commitment}

Theory of unification between the commitment and the theory of prospective states that every individual in some organization must have a commitment to advancing (affective commitment), comply with the rules (normative commitment), embodies the continuity of (continuance commitment) and clarify the prospective organization (prospective commitment) to achieve its goals (Smith and Meyer, 2009: 56). Understanding this achievement commitment, supported by several previous studies, that the organizational commitment has a positive and significant effect on job satisfaction (Chamdan, 2013), organizational commitment have a positive and significant effect on performance (Andi Harmoko, 2014; Wilson, 2013).

$\mathrm{H}_{5} \quad$ Organizational commitment has a positive and significant effect on Lecturers' job satisfaction

$\mathrm{H}_{6} \quad$ Organizational commitment has a positive and significant effect on lecturers performance

\section{Lecturers' job satisfaction}

Lecturers' job satisfaction refer on theoretical expectations or Herzberg's motivator and Hygiene Factors explaining that satisfaction is a disclosure happy and dissatisfaction is the disclosure disappointed both of these different. There are five aspects of job satisfaction, namely the maintenance of job satisfaction in the responsibility, embodies the progress (advancement), achievement, recognition and the work itself (Rivai, 2008: 255).

An understanding of this theory is supported by several previous investigators, that job satisfaction is positive and significant effect on performance (Nabizadeh, 2012; Sosiawan, 2013; Chamdan, 2013), job satisfaction has negative and insignificant on organizational behavior and lecturers performance (Ashari, 2012), job satisfaction has a negative effect on performance (Harprianti, 2010), job satisfaction has a positive and significant effect on performance (George Michael, 2011).

$\mathrm{H}_{7} \quad$ Lecturers' job satisfaction has a positive and significant effect on lecturers performance

\section{Lecturers' performance}

Assessment of performance used in this study is the theoretical results of Norton (2006: 48) states that the performance is a result of work to achieve organizational goals. Included in this faculty judged on results that reflect the activities of the three responsibilities of Higher Education cover the achievements in the field of education, research, community service and support activities. In addition, research on the performance of, among others, studied by previous researchers, that the individual performance has a positive and significant effect on job satisfaction (Nabizadeh, 2012; Sosiawan, 2013; Chamdan, 2013), creation of individual high-performance effect on job satisfaction (Solomon, 2010) , individual performance is affected positively and significantly on job satisfaction and organizational commitment (Chamdan, 2013), individual performance is positive and is not significantly affected by the competence, motivation and organizational commitment (Jack Harmston, 2008).

$\mathrm{H}_{8} \quad$ Work Motivation has a positive and significant effect on lecturers' performance. The Mediating role of lecturers' job satisfaction

$\mathrm{H}_{9} \quad$ Competence has a positive and significant effect on lecturers' performance. The Mediating role 
of lecturers' job satisfaction

$\mathrm{H}_{10} \quad$ Organizational commitment has a positive and significant effect on lecturers' performance. The Mediating role of lecturers' job satisfaction

\section{Research Methods}

This study was designed to address problems that have been formulated and the goals to be achieved and to test the hypothesis. The type of data in this study consisted of primary and secondary data. Sources of data obtained from the parties associated with this research. The parties in question is led 8 Polytechnic under the auspices of the Ministry of Industry of the Republic of Indonesia to obtain a variety of information that support the completeness of the data. The populations in this study are all lecturers within the Ministry of Industry of the Republic of Indonesia, which amounted to 409 people. Determination of the sample using the formula Slovin that the total samples in this study amounted to 202 respondents of correspondence via Intranet. Data analysis techniques used in explaining the phenomenon in this study is a descriptive statistical analysis techniques and analysis of structural equation modeling by AMOS (Analysis of Moment Structures) Version 18.

\section{Analysis and Discussion}

Based on the method of determining the value in the model, the first model testing variables are grouped into exogenous variables and endogenous variables. An exogenous variable is a variable whose value is determined outside the model. While endogenous variable is a variable whose value is determined by an equation or model-established relationships. Included in the group of exogenous variables are the motivation, competence and commitment to the organization, while those classified as an endogenous variable is job satisfaction and performance Lecturer. The model is said to be good when the hypothetical model development is theoretically supported by empirical data. Detailed SEM analysis results are shown in the following figure:

Figure 1. Initial model

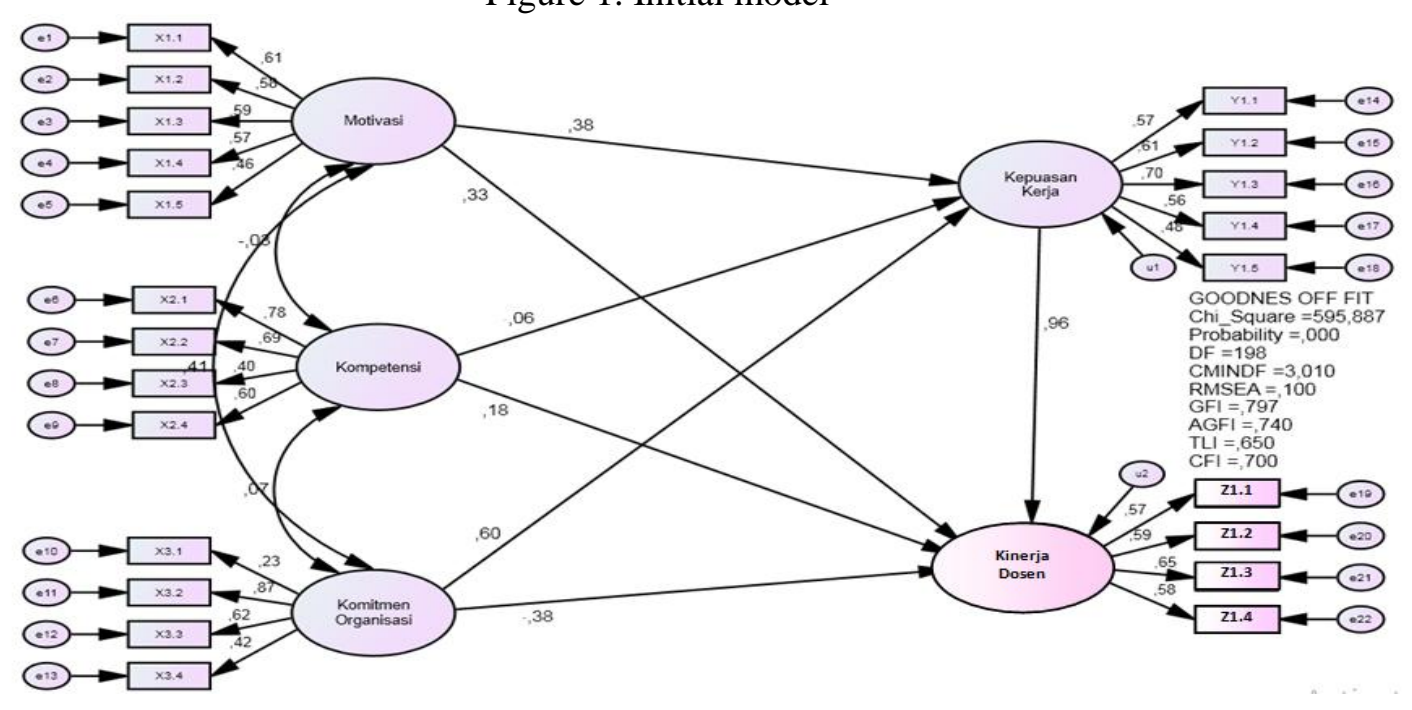

The evaluation shows models of the eight criteria of goodness of fit indices seen the value of chi-square still looks great and some of the criteria are not in accordance with the specified cutoff values, so that the modification models by performing the correlation between error indicators in accordance with the instructions of the modification indices. The results of the analysis after the final models obtained are as follows: 
Figure 2. The final model

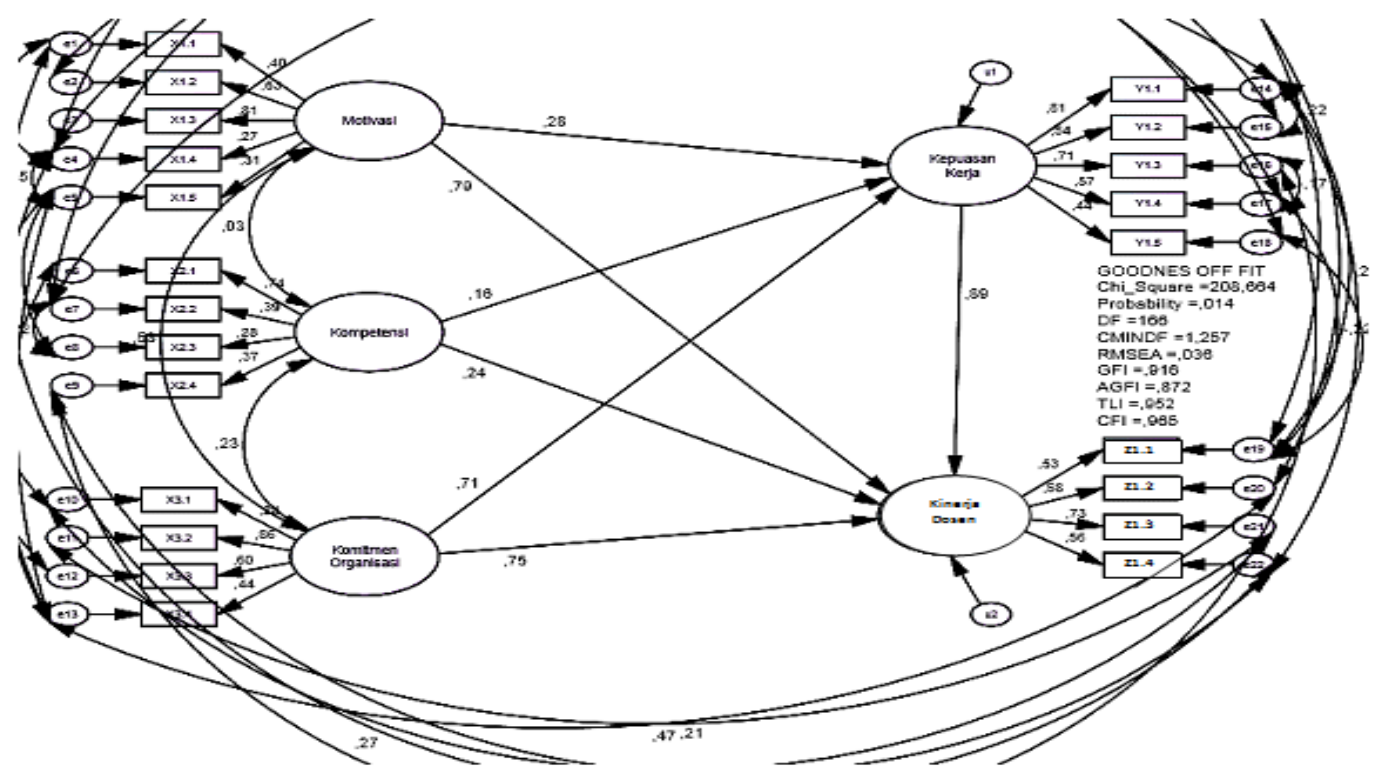

The model test results are presented in Figure 2 above, are evaluated based GFI (goodness of fit indices) in Table 2, presented the criteria of the model as well as critical values that have compatibility data.

Table 2 Evaluation criteria of goodness of fit indices overall model

\begin{tabular}{|c|c|c|c|c|c|}
\hline GFI & Cut-off Value & Initial model & Description & Final model & Description \\
\hline$\chi^{2}-$ Chi-square & $\begin{array}{c}\text { Small } \\
\text { Expected }\end{array}$ & $\begin{array}{c}595.887> \\
0,05: 198=231,829\end{array}$ & Marginal & $\begin{array}{c}208.664<(0,05: 206= \\
297.064)\end{array}$ & Good \\
\hline Probability & $\geq 0.05$ & 0.000 & Marginal & 0.054 & Good \\
\hline CMIN/DF & $\leq 2.00$ & 3.010 & Marginal & 1,257 & Good \\
\hline RMSEA & $\leq 0.08$ & 0.100 & Marginal & 0.036 & Good \\
\hline GFI & $\geq 0.90$ & 0.797 & Marginal & 0.916 & Good \\
\hline AGFI & $\geq 0.90$ & 0.740 & Marginal & 0.972 & Good \\
\hline TLI & $\geq 0.95$ & 0,650 & Marginal & 0,952 & Good \\
\hline CFI & $\geq 0.95$ & 0.700 & Marginal & 0.965 & Good \\
\hline
\end{tabular}

The results of the evaluation model for early stage shows of the eight criteria of goodness of fit indices are not yet eligible entirely cut off value, which still needs to be modified in accordance with the instructions of the model modification indices, as previously described. After the modification of the model, then the final stage shows the overall criteria for goodness of fit indices have met the criteria or according to criteria of the cut-off value, so that the model can be said to have been in accordance with the criteria of goodness of fit indices for analysis. 
Overall based empirical model are shown in the following table regarding the direct effect and the indirect effect of the variables studied. From the whole of the model there are six lanes provide a direct positive influence and significant, one-lane direct influence positive and not significant. Furthermore, the indirect effects of three independent variables have a positive impact through intermediate variable on the dependent variable. The test results are presented in the following table:

Table 3 Hypothesis testing direct, indirect and total effect

\begin{tabular}{|c|c|c|c|c|c|c|c|c|}
\hline \multirow[b]{2}{*}{$\begin{array}{l}\text { Hypothesis } \\
\text { Number }\end{array}$} & \multirow[b]{2}{*}{ Exogenous } & \multirow[b]{2}{*}{ Intervening } & \multirow[b]{2}{*}{ endogenous } & \multicolumn{4}{|c|}{ Standardize } & \multirow[b]{2}{*}{ Description } \\
\hline & & & & Direct & Indirect & Total & $\begin{array}{c}\text { P- } \\
\text { Value }\end{array}$ & \\
\hline 1 & $\begin{array}{l}\text { Work } \\
\text { motivation }\end{array}$ & - & $\begin{array}{l}\text { Lecturers' } \\
\text { job } \\
\text { satisfaction }\end{array}$ & 0,284 & - & 0,284 & 0,007 & Significant \\
\hline 2 & $\begin{array}{c}\text { Work } \\
\text { motivation }\end{array}$ & - & $\begin{array}{c}\text { Lecturers } \\
\text { performance }\end{array}$ & 0,790 & - & 0,790 & 0,000 & Significant \\
\hline 3 & Competence & - & $\begin{array}{c}\text { Lecturers' } \\
\text { job } \\
\text { satisfaction }\end{array}$ & 0,157 & - & 0,157 & 0,070 & Insignificant \\
\hline 4 & Competence & - & $\begin{array}{c}\text { Lecturers } \\
\text { performance }\end{array}$ & 0,239 & - & 0,239 & 0,044 & Significant \\
\hline 5 & $\begin{array}{c}\text { Organizational } \\
\text { commitment }\end{array}$ & - & $\begin{array}{c}\text { Lecturers' } \\
\text { job } \\
\text { satisfaction }\end{array}$ & 0,705 & - & 0,705 & 0,000 & Significant \\
\hline 6 & $\begin{array}{c}\text { Organizational } \\
\text { commitment }\end{array}$ & - & $\begin{array}{c}\text { Lecturers } \\
\text { performance }\end{array}$ & 0,748 & - & 0,748 & 0,001 & Significant \\
\hline 7 & $\begin{array}{c}\text { Lecturers' job } \\
\text { satisfaction }\end{array}$ & - & $\begin{array}{c}\text { Lecturers } \\
\text { performance }\end{array}$ & 0,889 & - & 0,889 & 0,000 & Significant \\
\hline 8 & $\begin{array}{c}\text { Work } \\
\text { motivation }\end{array}$ & $\begin{array}{c}\text { Lecturers' } \\
\text { job } \\
\text { satisfaction }\end{array}$ & $\begin{array}{c}\text { Lecturers } \\
\text { performance }\end{array}$ & 0,790 & 0,252 & 1,043 & 0,000 & Significant \\
\hline 9 & Competence & $\begin{array}{c}\text { Lecturers' } \\
\text { job } \\
\text { satisfaction } \\
\end{array}$ & $\begin{array}{c}\text { Lecturers } \\
\text { performance }\end{array}$ & 0,239 & 0,240 & 0,479 & 0,044 & Significant \\
\hline 10 & $\begin{array}{l}\text { Organizational } \\
\text { commitment }\end{array}$ & $\begin{array}{c}\text { Lecturers' } \\
\text { job } \\
\text { satisfaction }\end{array}$ & $\begin{array}{c}\text { Lecturers } \\
\text { performance }\end{array}$ & 0,748 & 0,627 & 1,375 & 0,001 & Significant \\
\hline
\end{tabular}

The interpretation of Table 3 for the direct and indirect effect can be described as following:

a. Work motivation has a positive $(0,284)$ and significantly $(0,007)$ effect on lecturers' job satisfaction.

b. Work motivation has a positive $(0,790)$ and significantly $(0,000)$ effect on lecturers performance.

c. Competence has a positive $(0,157)$ and insignificant $(0,070)$ effect on lecturers' job satisfaction.

d. Competence has a positive $(0,239)$ and significantly $(0,044)$ effect on lecturers performance.

e. Organizational commitment has a positive $(0,705)$ and significantly $(0,000)$ effect on lecturers' job satisfaction

f. Organizational commitment has a positive $(0,748)$ and significantly $(0,001)$ effect on lecturers performance.

g. Job satisfaction is directly positive $(0,889)$ and significantly $(0,000)$ effect on lecturers performance.

h. Motivation indirectly through job satisfaction has a positive $(0,252)$ effect and significant $(0,000)$ on lecturers performance

i. Competence indirectly through job satisfaction has a positive $(0,240)$ effect and significant $(0,044)$ 
on lecturers performance

j. Organizational commitment indirectly through job satisfaction has a positive $(0,627)$ effect and significant $(0,001)$ on lecturers performance

\section{Conclusion}

Based on the problems and the proposed hypothesis, the conclusions of this study are: 1) directly motivation and organizational commitment and significant positive effect on job satisfaction, except competence and no significant positive effect on job satisfaction; 2) direct motivation, competence and organizational commitment and significant positive effect on performance; 3) direct job satisfaction positive and significant impact on performance; and 4) indirectly motivation, competence and commitment to the organization through job satisfaction and significant positive effect on lecturers performance

On the overall hypothesis, only the direct competence and no significant positive effect on job satisfaction. These are the findings that should be improved, in particular to improve and develop the competence of lecturers are still low either ability, professional pedagogy, personal and social in supporting teaching and learning activities that occupied the lecturer will give a significant effect on work satisfaction.

\section{References}

1. Algredo, Marshall, (2007). Performance by Human Resource Management Handbook. Published. Ohio University Press.

2. Allen, S., and Meyer, G., (2009). Organization Commitment in Management Perspective. Published by Prentice Hall, New York.

3. Ancok, Jamaluddin \& Singarimbun, (2005). Survey Research Methods. Jakarta: LP3ES.

4. Bangun, Wilson, (2013). Human Resources Management. Publisher, Jakarta.

5. Handoko, Hani T., (2011). Fundamentals of Motivation. Publisher Liberty, Yogyakarta.

6. Norton, George, (2006). Management and Performance in Work. Published John Wiley and Sons, New York.

7. Rival, Veithzal, (2008). Human Resource Management. Publisher RajaGrafindo Persada, Jakarta.

8. Rival, Veithzal, (2010). Performance Appraisal. Press Publisher Rajawali, Jakarta

9. Rival, Veithzal, (2010). Performance Appraisal. Raja Grafindo PT Persada, Jakarta.

10. Rival, Veithzal, (2014). Human Resource Management for the Company from Theory to Practice. Third Edition, Eagle Press, Jakarta.

11. Warritten, Harold, (2007). Essentials of Management. Fifth Edition, McGraw Hill, Inc., Singapore. 